\title{
AN INCIDENT IN THE PRRI/PERMESTA \\ REBELLION OF 1958
}

\author{
Danie1 F. Doeppers
}

In February 1958 certain elements of the Indonesian Army participated in a revolt against the government of President Sukarno. This action was centered in the outer islands of Sumatra and Sulawesi (Celebes), and although the major cities had fallen to the government by June 1958, the rebellion sputtered on until 1961. The revolt failed in the face of unexpectedly resolute action by the Indonesian government. At that time there were charges that the United States participated in this conflict in a limited and clandestine fashion-on the side of the rebels. ${ }^{1}$ Except for the occasional rebel use of British or American military airfields, Western intervention has been difficult to trace to official agencies. This article presents evidence that a U.S. Navy reconnaissance plane, flown by a regularly assigned active duty crew, was very nearly shot down during a classified mission in the Sulawesi area on March 27, 1958.

\section{The Incident and the Evidence}

While searching for historical information on urban squatting in the Philippines the author read through eighteen years of the Mindanao Times, a reputable, remarkably long-lived, and generally "pro-America" Davao City newspaper (it routinely prints U. S. Information Service releases). During this laborious task, two articles were discovered which related to the 1958 affair. Both are here reprinted in full.

\section{U.S. PLANE FORCELANDS: STIRS TALKS IN DAVAO}

Navy Bomber's Wings Without Usual Marking

Wing Tip has Gaping Hole With Busted Pipeline

Say Landing Due to Engine Defect

A U.S. navy twin engine bomber, bearing serial number SS 128051 which forcelanded at the new runway in the SASA [Davao City] airport Thursday afternoon [March 27, 1958] stirred a speculation here.

While constabulary authorities and members of the crew explained that the plane developed engine trouble while on a proficiency flight over Davao, those who saw the plane brushed aside the explanation and expressed many conjectures.

1. James Mossman, Rebels in Paradise, Indonesia's Civil War (London: Jonathan Cape, 1961); David Wise and Thomas B. Ross, The Invisible Government (New York: Random House, 1964), chapter 8; William Stevenson, Birds Nests in their Beards (Boston: Houghton Mifflin Co., 1963); and Herbert Feith and Danie1 S. Lev, "The End of the Indonesian Rebellion," Pacific Affairs, XXXVI (Spring 1963), pp. $32-46$. 
The twin engine aircraft, which landed on the 1,500 meter new concrete runway was being repaired at this writing.

Viewed by representatives of the Times, the plane showed that its right wing-tip near the gas tank has a gaping hole about three feet long and one-half foot wide.

No explanation was available on why or how the plane sustained this damage. The bomber which is whitish and unlike most dark-gray U.S. navy aircrafts, did not carry the usual markings underneath the wings. A small star under the right wing was painted white almost beyond recognition.

A UP report from Indonesia, meanwhile, disclosed that the Indonesian government forces seized Americanmade firearms believed dropped for the rebels by a "foreign unidentified aircraft" the other day.

The firearms which were allegedly dropped in Pakambaru, central Sumatra, were reportedly shown to diplomatic missions in Indonesia. Another U.S. navy plane, meanwhile arrived here yesterday with spare parts and mechanics to repair the damage.

Earlier report stated that the plane's radio was dead and that plane Commander Mendenhall had to use the Philippine Air Line's radio to report the incident to his base headquarters.

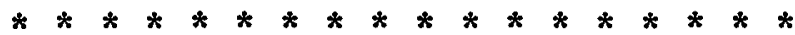

\section{U.S. AIRFORCE BIRD THANKS MAYOR PORRAS}

Capt. H. V. Bird, acting commander of the U.S. Naval Forces in the Philippines in a letter to [Davao] Mayor Carmelo L. Porras recently, extended the gratitude of the U.S. Navy "for the warm friendliness and cooperative spirit shown by your people."

Bird referred to the stay here of members of the U.S. Navy plane crew who landed here in an emergency two months ago. The crew brought to Bird's attention the "warm hospitality and many courtesies extended to them during their stay." Wrote the navy commander: "on behalf of the U.S. Navy, I would like to take this opportunity to thank you and the people of Davao for many instances of true understanding, spontaneous generosity, and valuable assistance shown these men while in your city."

Bird continued, "The warm friendliness and cooperative spirit will be remembered as one of the priceless assets of the U.S. Navy in the Republic of the Philippines."2

2. "Navy Bomber's Wings Without Usual Marking," Mindanao Times (March $29,1958)$, pp. 1 and 4 , and "U.S. Airforce Bird Thanks Mayor Porras," Mindanao Times (May 7, 1958), p. 4. 
Having chanced on these scraps of history, I wondered about their accuracy and was later able to check out a number of specific points.

\section{The Aircraft}

The Mindanao Times identified the plane which made an emergency 1 anding as a "U.S. Navy twin engine bomber, bearing serial number SS 128051." From 1953 until its gradual replacement circa 1959, the AJ-2 "Savage" was the Navy's principal long-range, carrier-based, heavy attack bomber. It was powered by twin wing-mounted reciprocating engines. In addition there was also an aft center-mounted turbojet. Except for a small tail pipe, however, the small jet engine was entirely concealed within the bulk of the fuselage. The jet's intake was located on the dorsal ridge--out of view of a ground level observer. In short the AJ-2 heavy attack bomber (built to carry an atomic weapon off the deck of a carrier) looked like a heavy twin engine plane. ${ }^{3}$ At a cruise speed of 230 miles per hour the AJ- 2 had a one way range of about 1,600 statute miles. With the turbojet in use it could attain a true air speed of 460 miles per hour.

A specialized version of this plane, the AJ-2P, was designed for long range photo reconnaissance. It carried flares for night photography but was not armed. Except for an extra camera lens nipple the AJ-2P was almost indistinguishable in appearance from the more common AJ-2.4 In 1950 the U.S. Navy placed an order for twenty-three AJ-2P's with the North American Aviation factory in Columbus, Ohio. Factory records reveal that the eleventh plane built under this contract was number $128051 .{ }^{5}$ The plane was delivered to the Navy around 1953.

In Sum, there definitely was an aircraft designated 128051 in the U.S. Navy's inventory, and it looked very much like a "twin engine bomber."

\section{The Squadron}

The Mindanao Times article identified the aircraft in question with the prefix "SS." These double letters are a short hand sign for the particular squadron to which the aircraft and its crew were assigned. The fact that the first letter falls in the latter half of the alphabet already indicates that the squadron was assigned to the

3. Jane's All the World's Aircraft, 1955-1956, pp. 298-299. See also Office of Chief of Naval Operations, Naval Aviation in Review, Navaer 00-80T-58, 1958, and Naval Aviation News (November 1958), p. 17 .

4. For an account of the AJ-2P's purposes and capabilities see "Cameras Are Their Weapons," Naval Aviation News (November 1958), pp. 7-12.

5. This information was kindly provided by $\mathrm{Mr}$. James Tichenor, Public Relations Office, North American Rockwe11, Columbus, Ohio, in conversations on March 8 and 9, 1971. 
Pacific fleet. But, more specifically, the Navy confirms that "SS 128051" was assigned to Heavy Photographic Squadron Sixty-One (VAP-61).6 Then, as now, this squadron was stationed on Guam. From there small detachments range widely, carrying out specific assignments for a variety of federal agencies. Some of the purposes and activities of VAP-61 were discussed in Naval Aviation News during 1958.

In war or peace, photographic squadrons provide aerial photographic intelligence in support of naval operations. Obtaining complete coverage of sensitive areas is absolutely essential. Since stockpiled intelligence becomes obsolete rapidly, new material must be gathered continuously.

$\star * * * * * * * * * * * * * * * *$

Pictures of target run-ins are invaluable in briefing attack squadron pilots. Shot from an altitude of several hundred feet to 40,000 feet with various focal length cameras, photographs aid air intelligence officers to brief pilots accurately on target location and identification. ${ }^{7}$

\section{The Color and Star Insignia}

A star identification insignia appears on the underside of the right wing of all standard U.S. Navy planes. The reporter for the Mindanao Times was justified in suspecting something amiss upon discovering that the right underwing insignia "was painted white almost beyond recognition." On the other hand he was incorrect in stating that most U.S. Navy aircraft were dark gray in color. The color scheme for Navy carrier aircraft was changed during 1956 to a lighter shade. (A light or white color tends to reflect rather than absorb the flash of a nuclear detonation.)

\section{The Men}

The Mindanao Times named a "plane Commander Mendenha11." In 1958 there were six commissioned or warrant officers named Mendenhall on active duty with the U.S. Navy. Only one was a qualified naval aviator (pilot) and a Commander. He was Sy E1ton Mendenhall (born 1919), regular line officer, graduate of the General Line School, and holder of the Distinguished Flying Cross. ${ }^{8}$ Military records indicate

6. Letter from the Public Affairs Officer of COMNAVAIRPAC (Commander Naval Air Force, United States Pacific Fleet), N.A.S. North Island, San Diego, February 16, 1971.

7. November, 1958 , pp. 8 and 9 respectively. See also Naval Aviation News (January 1956), p. 31 and (February,1955), pp. 14-15.

8. Register of Commissioned and Warrant Officers of the United States Navy and Marine Corps and Reserve Officers on Active Duty, NAVPERS 15,018 (January 1, 1958), alphabetical index and p. 52. This

"Register" is updated and reissued every year. 
that S. E. Mendenha11 was not only assigned to VAP-61 in March 1958, but that he was its commanding officer as well.

The "Capt. H. V. Bird, acting commander of the U. S. Naval Forces in the Philippines," whose letter to the mayor of Davao City was quoted in the Mindanao Times, was Horace Virgil Bird. Bird was promoted to Rear Admiral in 1963 and is still on active duty. ${ }^{9}$ Bird was probably not in the direct chain of command for this particular flight, but rather entered in when the plane was forced to land at Davao.

Commander Mendenhal1, now retired from the Navy, recently confirmed these facts, i.e., that he did 1 and an AJ-2P reconnaissance plane at Davao City in March 1958 and that the plane had a substantial hole in the wing. I0 He declined to discuss those aspects of his mission he understood to be "classified." But it is possible to trace out what his mission must have been if one places it in the context of what was happening in Indonesia at that time.

The Indonesian Rebel1ion of 1958

1957 and 1958 were years of crisis for Indonesia. Severe economic problems, as well as the continuing revolt by the Darul Islam (a militant Muslim movement) troubled the Central government on Java, and regional movements, led by territorial commanders, challenged its mandate in the outer islands, particularly Sumatra and Sulawesi. On granting independence to Indonesia, the Dutch had retained a colonial toehold in western New Guinea (West Irian), and by 1957 Indonesia was demanding its return. When the United Nations refused to support Indonesia's case against the Netherlands, President Sukarno ordered the seizure of Dutch businesses and plantations. Not without logic on nationalist grounds, the move had a serious effect on the economy. In some cases Dutch enterprises were taken over by 1 abor unions, many of which were dominated by the PKI (Indonesian Communist Party)--thus giving rise to official American fears of a communist takeover.

At this time many of the territories outside of Java were to a large degree functionally autonomous and were virtually under the control of local army officers. This autonomy was in part maintained by smuggling, especially to Singapore, of local products such as crude rubber, copra, etc.

Conflicting interests between Java and the major outer islands are a fact of Indonesian life. Java supports a population of extraordinary density and must import many of its basic requirements. On the other hand, Sumatra, Borneo, and Sulawesi are very large islands with much lower population densities and considerable export surpluses. The regional commanders justified their smuggling by contending that Djakarta was not returning a fair share of the wealth derived from outer island resources, especially royalties from the oil fields of Sumatra and Borneo.

9. Register (1958), p. 12; (1963), p. 3, and (1970), p. 1 .

10. Telephone conversation, December $30,1971$. 
During the latter part of 1957 there were numerous conferences among the dissident military commanders of Sumatra and Sulawesi. By early 1958 they had been joined by several civilian leaders from Masjumi and the Indonesian Socialist Party (PSI), and on February 10 the group served an ultimatum on the Djakarta government. Their principal demands were the ouster of the cabinet led by Premier Djuanda with its unnamed "communist sympathizers," its replacement by a government without communist participation headed by Hatta and the sultan of Jogjakarta, President Sukarno's return to a constitutional position, and the abandonment of his efforts to implement Guided Democracy.1 When these demands were rejected, the rebels proclaimed a countergovernment (PRRI). The insurgent colonels entertained hopes that the commanders of other military regions in the outer islands (who certainly shared their sentiments) would also join in the demands, and reasoned that Sukarno was too weak and indecisive to move against them militarily. The rebels' confidence was increased by the supportive attitude of the United States. On the day after the rebe1s' ultimatum, Secretary of State Dulles stated at a press conference in Washington:

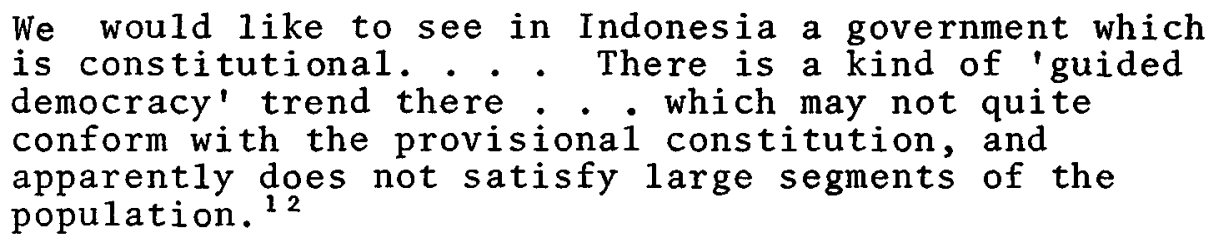

Central Sumatra, the home area of the Moslem Minangkabau was the original center of the revolt (Figure 1). It was joined by Tapanuli to the north (the Christian Batak region) and by the distant Minahasa peninsula of northern Sulawesi, another Christian area. The commanders of Palembang and Atjeh (at opposite ends of Sumatra) did not, however, proceed to open rebellion.

To the shock of the rebels, President Sukarno and Chief of Staff Nasution took decisive action. By later February Indonesian Air Force B-25's and P-51's had begun bombing and strafing rebel groups in Sumatra and northern Sulawesi. The government imposed a blockade against the rebe1 regions, and Indonesian gunboats forced ships in the Straits of Malacca to stop at several checkpoints before proceeding to Singapore. Many vesse1s and their valuable cargoes of smuggled goods were impounded. Other ships were blockaded in the rivers of east Sumatra or in the ports of Padang and Menado. As Singapore's Straits Times observed on March 24, "While a few small smuggling boats may still be able to run the gauntlet of Jakarta's 500 assorted gunboats the grim fact is that Centra1 Sumatra's trade has come to a standstill."13

11. On this see Danie1 S. Lev, The Transition to Guided Democracy: Indonesian Politics, 1957-1959 (Ithaca, N.Y.: Cornell University, Modern Indonesia Project, Monograph Series, 1966), pp. 1-298.

12. Reported in Time (February 24, 1958), pp. 27-28.

13. (March 24, 1958), pp. 1 and 3. A11 this was a serious, though temporary, blow to the Singapore economy. In the same paper see the accounts of the blockade in the editions of March 1 , $3,4,17,1958$, etc. 
On March 12, government paratroopers dropped almost unopposed on the vital rebel "held" oil fields around Pakanbaru in Central Sumatra. ${ }^{4}$ After brief skirmishes the rebels withdrew to the interior. Despite the flurry of press releases from both sides there was little, if any, heavy fighting. The rebels knew the territory and clearly could carry on a persistent guerrilla campaign as they had against the Dutch--but would they? Rebel Prime Minister Sjafruddin was reported to have issued a statement that SEATO must recognize the rebels and choose sides "as they had in [the Civil War of] Spain."Is In an attempt to win official recognition the rebel Finance Minister, Dr. Sumitro, was dispatched to Washington. ${ }^{16}$ But on April 18, Padang was taken by the Indonesian army and marines almost without resistance. The fall of Bukittinggi, the rebel capital, just three weeks 1ater, signalled the end of the rebellion as a major movement on Sumatra. The rebellion had failed to achieve broad based support; only the Christian Batak area, some guerrilla bands in Atjeh, and the Minahasans of northern Sulawesi had been persuaded to join.

Despite its lack of political viability, the PRRI had clearly been expecting support from abroad and had apparently had little difficulty securing arms and munitions. Assurances had evidently been received from the "representatives" of certain Western powers that substantial help would be forthcoming, 17 and, in fact, a considerable amount of military equipment had already been delivered. When the Indonesian paratroopers dropped on Pakanbaru in the early morning of March 12, they surprised a group of rebels loading canisters of arms on trucks. Other canisters with parachutes still attached littered the ground. The military material seized that day also included "mobile anti-aircraft guns."18 A week earlier two American destroyers had arrived in Singapore, soon joined by the U.S. cruiser Bremerton, all of which, according to official reports,

14. The Straits Times (March 13, 1958), p. 1; (March 14, 1958), p. 2 and an eyewitness account (March 31, 1958), p. 3.

15. The Straits Times (March 26, 1958), p. 3. At the SEATO conference then being held in Manila, Secretary of State Dulles said that the question of extending recognition of belligerent status to the rebels was being examined by State Department "legal advisors," Ibid. (March 14, 1958), p. 2 .

16. Dr. Sumitro and Major Jan Pantouw left Singapore on April 1 as "radio operators" on an unscheduled plane operated by the Civil Air Transport company. The plane proceeded via Labuan in North Borneo and Manila. Major Pantouw had just returned from Honolulu three weeks earlier. The Straits Times (March 14, 1958), pp. 2 and 9 ; (March 20), p. 3; (Apri1 1), p. 1, and (April 3), p. 7 .

17. See Mossman's discussion of the role of United States Information Service library officials in Padang and Medan in trying to bring the Masjumi party into the revolt, and the comments of the British consul in Medan to the effect that he hoped the Colonels realized ". . that the Central Intelligence Agency isn't the same as the American Government." Mossman, Rebels, pp. 68-71. See also Stevenson, Birds, p. 145.

18. Mossman, Rebels, pp. 109-110; The Straits Times (March 14, 1958), p. 2, (March 15, 1958), p. 1, and (March 16, 1958), p. 14; Stevenson, Birds, p. 96, and Howard P. Jones, Indonesia: The Possible Dream (New York: Harcourt Brace Jovanovich, 1971), pp. 116-117. 
were standing ready to evacuate Americans from the Sumatran oil fields.19 Elsewhere there was speculation that these and other units of the Seventh Fleet might openly oppose the reimposition of Djakarta's authority over Sumatra. ${ }^{20}$

Reports of outside aid to the rebels persisted during the coming weeks. In April an anonymous correspondent in Sumatra encountered a forty-five man rebel patrol packing

- . astonishing firepower. Eight out of nine light arms were late-model, American-made, automatic weapons. The patrol had a 60-millimeter mortar, a couple of 3.5 inch bazookas, a pair of 57-millimeter recoilless rifles, and machine guns. ${ }^{2}$

The correspondent noted that this was more firepower than a U.S. army patrol had carried in Korea. Rebel officers with the patron volunteered that they had received brief training in the use of the various weapons from two foreigners in Padang. In April rebel soldiers manning a crossroads outpost at Taluk, Central Sumatra were interviewed by James Mossman. As he put it: "They had lit fires, and the plane had come and the weapons had floated down. Whose plane? Ah, that they couldn't say." 22 There were charges that the arms had been dropped by Royal Australian Air Force planes. ${ }^{3}$ The Australian Air Minister denied complicity. Lieutenant Colone1 Sukendro, Chief of Intelligence of the Indonesian Army, said that the air-dropped arms had been sent from Taiwan, though he did not explicitly implicate the Nationalist Chinese government. ${ }^{4}$

In late March The Straits Times reported

Mystery surrounds a Nationalist Chinese Civil Air Transport C 46 aircraft which has been making constant "test flights" from the Singapore Airport for the past three weeks.

The plane arrived in the Colony on March 6. ... The crew of the plane has been changed twice. The latest replacements flew into Singapore from Taipeh late last Saturday. . .

The crew appear to have nothing to do other than to make constant "test flights."

19. The Straits Times (March 12, 1958), p. 1 and New York Times (March $12,1958)$.

20. See Newsweek (March 17, 1958), pp. 42-44, (March 24, 1958), p. 44 and U.S. News and World Report (March 21, 1958), p. 83 .

21. U. S. News and World Report (April 18, 1958), p. 55, written by Regional Editor, Robert P. Martin. See also the same magazine (July 25, 1958), pp. 71-72.

22. Mossman, Rebe1s, p. 146.

23. The Straits Times (March 15, 1958), p. 1, and Newsweek (March 24, 1958), p. 40 .

24. The Straits Times (March 22, 1958), p. 1 . 


\begin{abstract}
Malayan Airways is looking after the plane "from the engineering side." 25
\end{abstract}

For its part

The Royal Air Force. . . denied that any of its airfields in Singapore had been used as bases for aircraft supplying the Sumatran rebels.

The denial followed a claim from Jakarta that Indonesian intelligence agents in Singapore had observed unidentified aircraft, which had been used for dropping arms to Sumatran rebels, landing at night at Changi [a British Air Base on Singapore island] for refueling. 26

From the rebel side Dr. Sumitro said the American-made arms captured at Pakanbaru were indeed dropped by Civil Air Transport. ${ }^{7}$ (Civil Air Transport, based in Taiwan, is the successor to General Chennault's World War II Flying Tigers and has often been linked to secret U.S. [i.e., CIA] activity in Asia. ${ }^{28}$ )

Despite the rapidly deteriorating situation in Sumatra, outside help for the rebels in Sulawesi increased in late April. There the rebels had mysteriously acquired a talented air force. Four Americanmade twin-engine bombers and two P-51's began ranging out from airfields near Menado. The straits Times reported that the first raid on the government airport at Makassar was made on April 13. ${ }^{9}$ The British tanker San Flaviano was bombed and destroyed at the Royal Dutch Shell facility at Balikpapan on April 28. The next day Lloyd's of London reported that a Greek steamer had been strafed while carrying survivors of an Italian freighter sunk by the rebel air force. ${ }^{3} 0$ On the Banda Sea and in the Makassar Straits, Panamanian and Indonesian merchantmen also suffered strafing casualties. ${ }^{31}$ And an Indonesian Navy corvette was sunk in the harbor of Ambon. For a time in the second half of April and early May, Djakarta's naval blockade of Menado was disrupted. ${ }^{32}$

25. "Plane Mystery," The Straits Times (March 28, 1958), p. 6. The same plane left Singapore on April 1 with Dr. Sumitro and Major Pantouw as passengers. "2 Rebel Leaders Do a Cloak and Dagger Air Exit," The Straits Times (Apri1 1, 1958), p. 1. The Indonesian government asked Singapore to ban such planes. The Straits Times (Apri1 3, 1958), p. 7 .

26. The Straits Times (April 15, 1958), p. 1 .

27. Stevenson, Birds, p. 135 .

28. For example Wise and Ross, The Invisible, chapter 8.

29. The Straits Times (April 15, 1958), p. 1 .

30. The Straits Times (April 29, 1958), pp. 1 and 3, and (Apri1 30, 1958), pp. 1 and 9 .

31. Only after substantial delay was news of these strikes printed in Time (May 21, 1958, p. 33) and Newsweek (May 19, 1958, pp. 50 and 52 .

32. During this period the rebels received arms by ship from Taiwan. Mossman, Rebe1s, p. 222 . 
On April 29, the rebels announced that, following sustained bombing, their troops had captured the airfield on Morotai, a small island north of Halmahera (the runway there was originally built and used by General MacArthur's allied command during 1944 and 1945). ${ }^{33}$ For the next several weeks the rebel air force continued to harass the sea lanes, ports, and airfields within the arc of Menado and Morotai. ${ }^{34}$

It was not until the end of May that the rebel planes ceased their raids. A month later, after stiff ground fighting, Menado fe11. Despite continued guerrilla fighting which tied down several battalions of government troops until 1961, the rebellion as a broad movement was over. On May 20, John Foster Dulles said that the United States, too, had once suffered civil war and it was his view that the current civil war should be handled as an internal matter by Indonesians "without intrusion from without."35 Modest aid for President Sukarno's government was soon announced in Washington.

For some time much of the American press appeared to be mystified by these planes and their skillful pilots. Commonwealth journalists James Mossman and William Stevenson, however, separately reported that each had interviewed Minahasan sailor-smugglers in British North Borneo who had seen a number of Americans in Menado and understood them to be pilots of the rebel war planes. Mossman, whose stories appeared in the Australian press, claims that soon thereafter some Americans approached the Australian Department of External Affairs in Canberra and suggested that his presence on the scene could be embarrassing to the West. ${ }^{36}$ Stevenson later wrote that the rebel bombers reached Menado from Taiwan by way of the Labuan Island airfield in British North Borneo. One of his sources said

These bombers fly in [to Labuan] from Formosa, see. Night landings. Quick refuel job, then orf [off] at first light. Mostly dropping supplies to these rebels, like. Sometimes they've bombed Indonesian ports. . . The planes are painted black, no identification. Crews

33. The Straits Times (April 30, 1958), p. 1 .

34. Clearly all this represented an attempt to neutralize the approaches to Minahasa, to deny the central government vital revenues, and to pressure President Sukarno by disrupting the channels of interisland and foreign circulation. It may also have been an attempt to force economic decentralization and breakup by pushing merchant marine insurance rates up to the point that regular shipping could no longer enter the area.

35. Jones, Indonesia, p. 149 .

36. Mossman, Rebels, p. 201 and Stevenson, Birds, p. 213. U. S. News and World Report (May 9, 1958), p. 37 was least equivocal among the American magazines: "There is no mystery about the planes. They are B-25 Mitche11s, U.S. made twin-engine light bombers which came from Formosa. Most probably they are part of an unofficial 'lend-lease' arrangement among anti-communists in Asia." What was to be "leased" in return for the "loan" was not mentioned. 
are Chinese and Yanks. Nice young fellers, in civies. Well paid too. ${ }^{37}$

Any doubt about the accuracy of these accounts was dispelled by the events of May 18, when one of a small group of black, unmarked twinengine planes bombing and strafing Ambon harbor and town was shot down--its pilot an American named Allan Lawrence Pope. ${ }^{3}$ It later came out that Pope, from Dade County, Florida, had flown 55 combat missions in the Korean War while serving in the United States Air Force and had won the Distinguished Flying Cross. After Korea he flew for Civil Air Transport. Then in 1958 he took "leave of absence" to fly for the rebels, presumably at the behest of the CIA--at a reported salary of $\$ 10,000$ a month.

Given this context, the incident of March 27, 1958 at Davao's new civil airport can be more easily understood. The Mindanao Times article and two eyewitnesses interviewed by this author in 1969 indicated that the explanation of engine failure was a prevarication. In their view, the AJ-2P could only have been so damaged by cannon (i.e., anti-aircraft) fire. Clearly the plane could not return to one of the U.S. military airfields on Luzon because the damage it had suffered made it imperative to land as soon as possible; a carrier landing would have been even more hazardous. A small protrusion in an airplane's wing surface--to say nothing of a three foot hole--causes a plane to yaw dangerously toward the damaged side. Further, the "busted pipeline" may have meant loss of fuel or of the hydraulic pressure necessary to operate the flap system. In that case, a high speed landing approach and a long runway would have been required. Clearly, the mission ended safely only because of an extraordinary feat of piloting.

What had SS 128051 been up to and how was it damaged? The fact that the plane had its official insignia deliberately obliterated by white paint indicates the clandestine nature of its flight. Also the mission was clearly one of great importance or it would not have been flown by the squadron commander himself--the highest ranking and most experienced pilot available.

On several grounds it can be deduced that the photographic targets of the mission were in the general area of Sulawesi. Because flying and landing so damaged an aircraft entailed grave risk, one can be certain that Davao was the substantial "friendly" airfield nearest the

37. Stevenson, Birds, p. 193. Ambassador Jones reports that in early May, 1958 a member of his staff visited the U.S.A.F.'s Clark Air Base in the Philippines and saw a "plane with wings painted black in one corner of the field" and thus assumed U.S. Government knowledge and permission for help being given the rebels. Jones, Indonesia, p. 143 .

38. Pope was tried, convicted, and held by the Indonesian Government until July 2, 1962, when he was quietly flown back to the United States. Six months later he was flying for another clandestine American air service. Wise and Ross, The Invisible, chapter 8; Jones, Indonesia, pp. 129-130 and 140-141; "Captive Adventurer," Newsweek (June 9, 1958), pp. 40 and 45 and (January 11, 1960), p. 41; Time (May 9, 1960), p. 35, and Stevenson, Birds, pp. 193215 . 
place where the damage was sustained. Because of the distance involved, it is quite unlikely that the Mindanao Times was correct in inferring that the plane had been damaged over Pakanbaru.

March 27 was before the first rebel air raids in East Indonesia. It is most likely that the AJ-2P was gathering photographic intelligence on the facilities and defensive arrangements of various harbors and airfields in the area, including Makassar and Morotai. To requote the U. S. Navy on the purpose of this plane--"pictures of target runins are invaluable in briefing attack squadron pilots." ${ }^{9}$ Obviously, the aircraft was damaged while making a low altitude pass, but, until further information is made available, the exact "targets" of the mission will remain in doubt. Nevertheless, one may speculate that the photographs obtained by SS 128051 were used in the subsequent raids on Sulawesi ports by the American-piloted bombers.

One further question remains to be answered. On whose instructions did the March 27 flight take place? Rear Admiral D. L. Kauffman, who a decade later followed Bird in command of American naval forces in the Philippines area, told the author that during his own tenure orders for so sensitive a flight would have come from the White House. ${ }^{40}$ But this may have been an arrangement of the Johnson era. Commander Mendenhall recalls that his orders were issued by the Pacific headquarters in Hawaii (CINCPAC), but is certain that they were authorized by the Chief of Naval operations and possibly by the White House (Nationa1 Security Counci1).

Unfortunately, the information concerning this mission is insufficient to resolve the question of whether CINCPAC (from its naval bias) promoted the rebellion and perhaps tried to give the Pentagon a fait accompli, but was ultimately forced to abandon the failing rebels ${ }^{41}$ or whether, as is generelly accepted and as I believe, the brothers Dulles cooked up the rebellion, hired the bombers, etc., but called on the Navy for the specialized craft and crew need for prestrike photographic intelligence gathering. The point is that in either case the authorization of a U.S. Navy mission involves government officials--not just the "intelligence-community" types who have often enough appeared to operate without the detailed knowledge of official Washington to say nothing of ambassadors on the scene. ${ }^{42}$

39. See footnote 7 .

40. Conversation, June 18, 1971.

41. This line of reasoning is suggested by Dr. Sumitro.

There was a time when we had the support of the United States Seventh Fleet. But then the United States opposed us, and said we were not much better than bandits. It became a struggle between Pearl Harbor and the Pentagon. . . Y Yes. It was Pear1 Harbor against the Pentagon.

(Interview with Stevenson, Birds, p. 236.) In contrast to the Navy the U.S. Army may have opposed aiding the rebellion for fear of undermining or alienating anti-communist Indonesian Army leaders.

42. See Wise and Ross, The Invisible, "Burma: The Innocent Ambassador," pp. 129-135 and Jones, Indonesia, pp. 143-145. Former Ambassador Jones makes no mention of the rebel use of the old MacArthur base 
Recently Howard P. Jones, U.S. Ambassador to Indonesia during the rebellion, has written that the United States supplied military aid to the rebels, but that he, as ambassador, was not privy to this policy. ${ }^{43}$ Indeed Jones went to great lengths to report to Washington that Dr. Mohammad Hatta, Chief of Staff Abdul Haris Nasution (a Sumatran), and other influential Indonesians in Djakarta saw this rebellion not as a struggle centered on "communism" but rather as a distressing attempt to break up the Indonesian state. Apparently ignoring such counsel, Secretary of State John Foster Dulles and his brother Allen, head of CIA, chose to deal with the situation as an adjunct of the Cold War. ${ }^{44}$ For the most part military material and other help appear to have been delivered or carried out through secret "non-official" organizations. These charges were denied by President Eisenhower and Secretary Dulles, both of whom said that any Americans participating in the rebellion were "soldiers of fortune" over whom the United States Government had no contro1.45

on Morotai, the destruction of the British tanker at Balik apan, or whether the British ambassador knew of the rebel use of Labuan and other airfields.

43. Jones, Indonesia, p. 143.

44. Ibid., pp. 118, 121, 138, and 143-145.

45. Ibid., pp. 131 and 134-135. 